\title{
CORPORATE GOVERNANCE UNDER MULTI- THEORETICAL PERSPECTIVE
}

\author{
Muhammad Hassan ${ }^{1}$ \\ Institute of Management Sciences, \\ Bahauddin Zakariya University, Multan \\ Muhammad Rizwan ${ }^{2}$ \\ Institute of Management Sciences, \\ Bahauddin Zakariya University, Multan
}

\begin{abstract}
This study examines the impact of corporate governance reforms (SECP code in Pakistan) on board structural characteristics, board roles and firm performance. It uses an exclusive balanced panel data set of 200 companies listed on Karachi Stock Exchange. The study contributes to a sparse empirical literature on boards using data from Pakistan via multi-theoretic perspective to prove that if the boards' monitoring and resource provision roles are strengthened through board restructuring, the financial performance of the organization will be strengthened. The main findings of the study indicate that the mediated relationship between board structural variables and firm performance is stronger. The study concludes that overall companies adopted a box-ticking approach for reporting corporate governance.
\end{abstract}

Key Words: Corporate Governance, Agency theory, Resource dependence theory, Pakistan

* The material presented by the author does not necessarily portray the viewpoint of the editors and the management of the Institute of Business \& Technology (IBT)

1. Muhammad Hassan :hassanbucha@hotmail.com,

(C) IBT-JBS is published by the Institute of Business and Technology (IBT). Main Ibrahim Hydri Road, Korangi Creek, Karachi-75190, Pakistan. 


\section{INTRODUCTION}

The area of corporate governance has generated a large amount of interest both in the academic and public debates in the last two decades. The wide ranging scholarship regarding corporate governance has adopted a finance and economics perspective by adopting Agency theory as their primary research mechanism (Shleifer and Vishny, 1997; Gompers et al., 2003; Dahya and McConnell, 2005).

However, recently many researchers (e.g., Daily et al, 2003; Ghoshal, 2005; Roberts et al, 2005) has raised questions on the capacity of agency theory to cover all aspects of corporate governance. Specifically, many researchers in the field of corporate governance consider the assumptions of agency theory too narrow to identify and explain the board roles performed at various organizations (Roberts et al., (2005; Pye and Pettigrew, 2005; and Aguilera, 2005). These shortcomings of agency theory have encouraged the scholars in the field of corporate governance to develop and propose an alternative theoretical framework. The closest alternative theoretical framework available to researchers has been Resource dependence theory (Pfeffer and Salancik, 1978). However, the researchers such as (Hillman and Dalziel, 2003, Hermalin and Weisbach, 2003) are of the view that there is no single theoretical framework comprehensive enough to explain the dimensions of corporate governance in its entirety rather they are of the view that there is need to look on corporate governance particularly board related research through a multi-theoretic perspective.

In the more recent times, research in corporate governance has more progressively moved away from conventional studies examining directly the impact of board structural characteristics on firm performance towards a greater interest in mediation based studies, which examine the impact of corporate governance reforms on board structural characteristics and firm performance through some intervening or mediating mechanism like board roles (Van Ees et al., 2008; Wan and Ong, 2005; Zahra and Pearce,1989). This study maintains this convention by developing and examining a model, derived from the extensive literature, to investigate the function of board structural characteristics to strengthen the board roles and firm performance by combining agency and resource dependence theories perspective.

Therefore, this provides sufficient grounds for this study to question how board roles mediate their relationship between board structural characteristics and firm performance ?

Specifically, the objectives of this research are:

- To develop and examine a model of the relationships between board structural characteristics, board roles and firm performance;

- To investigate the factors affecting board structure and firm performance relationship under multi-theoretic lens;

- To develop recommendations for board members and policy-makers on their role to contribute to add value to the firm overall. 


\section{LITERATURE REVIEW}

Agency theory offers a well-established view on how to address the corporate governance problem associated with dispersed owners (Van Ees et al., 2009; Huse, 2005). Predominantly the agency theory has been using the areas of finance and economics to explain the success of Modern Corporation regardless of the separation of ownership and control functions. There has been not much literature to theoretically explain the success of modern organization except the seminal work of Berle and Means (1932) regarding the discussion on 'Separation of Ownership and Control' in modern corporations. The principal faces the agency problem when the agent starts behaving in his best interest as compared to the best interest of the principal. Shleifer and Vishny (1997) have described the agency problems as the costs needed to implement the mechanisms by the board on behalf of shareholders to judge that their money is being used in their best interest. Therefore, the agency costs include all costs involved to develop and maintain a structure to monitor the agents (Jensen, 1983).

The resource dependency theory based research has depicted that boards prove to be the resource of the organization and they help improve the character and repute of the organization to the investors in the outside world and provide guidance in policy making and advice to the management (Carpenter and Westphal, 2001; Westphal, 1999). Therefore, it may be inferred here that as more directors are added to the board size, the diversity and strength of the links increase to the external environment. This may help take better decisions on the basis of the board expertise and experience.

As Agency theory propounds more towards monitoring role of the board, the resource dependence theory leans towards resource provision role of the board (Hillman et al.,, 2000; Pfeffer, 1972; Pfeffer and Salancik, 1978). According to Pfeffer and Salancik (1978), there are expectations from organisations from board members in terms of the resources they provide.

The discussion made on the resources provided by the boards in the above paragraph makes it clear that effective boards would have the capability to fulfil both the resource dependence and monitoring roles of the board (Jensen 1993; Pfeffer and Salancik 1978; Reingold 2000). Thus, rather than relying on one or the other role, the study proposes an integration of the two ways of viewing board roles may be more valuable for both practical and theoretical reasons. Instead of relying on any one or the other role, we propose an integration of the two ways of viewing board roles may be even more valuable for both practical and theoretical reasons. Therefore, the study adopts a multiple-theoretical perspective and will consider board roles not only in agency theory perspective but also in the context of resource dependence theory.

Therefore, in combining the two theoretical perspectives, this study argues that board contributes both monitoring and the provision of resources. An important contribution of this study is a more fully specified and richer model of the relationship between boards' structure and firm performance mediated by board roles.

This study follows the theoretical proposition forwarded by Vafeas (1999) and Conger et al., (1998) that the frequency of board meetings measures the intensity of a board's monitoring role, and the quality or effectiveness of its monitoring. It has been argued that higher frequency of meetings will grant directors with more time and effort to design strategy and to appraise the CEO performance (Vafeas 1999). It can help directors to remain aware and informed about important developments taking place within the firm and putting the directors in a better position to timely address emerging critical issues (Mangena and Tauringana, 2006). Moreover, Sonnenfeld (2002) proposes that presence of directors in regular meeting is considered a quality of the diligent boards. This higher frequency of board meetings will 
bring the members closer to the organization and they can get sometimes important information through informal sideline communications (Lipton and Lorsch, 1992) which can be instrumental in strengthening the resource dependence role of the directors as well.

An overwhelming amount of scholarship have posted a positive relationship between board meeting frequency and the market based measure of performance (Karamanou and Vafeas, 2005) which indicate that companies having more frequent board meetings had a positive impact on the outside investors. However, to get back to the point about significance of meeting frequency to firm performance Lipton and Lorsch (1992) suggest that the higher meetings frequency is likely to result in superior performance. Therefore, generally there is reason to believe board meetings on face value, may be an important resource and therefore frequency of board meetings, may influence the governance performance nexus.

H1 (a): Frequency of board meetings is positively associated with firm financial performance (Tobin Q)

H1 (b): Frequency of board meetings is positively associated with firm financial performance (ROA)

The provision of resources through experienced and well-connected directors is directly associated with firm performance (Hillman et al., 2000; Yawson, 2006). The foremost advantage of the larger boards is that they become instrumental in access to critical resources like finance, raw materials, and vital information for the firm because of their background, expertise, and networking (Haniffa and Hudaib, 2006; Pearce and Zahra, 1992). Another very significant advantage of the larger boards is to enhance the knowledge base to design strategy for getting competitive advantage in managerial capability and better decision making (Yawson, 2006; Pugliese et al., 2009). The enhanced resource capability of the board also increases its capacity for better monitoring of the firm management which shows that larger boards may be better able to perform their control role in the organization (John and Senbet, 1998). The larger boards with diversified skill set of expertise will be better poised to ascertain the quality of decisions made by the CEO and in this way may neutralise the dominance of CEO.

The literature reports that there is a positive association between size of the board of a firm and its market based measure of financial performance Tobin Q (Henry, 2008; Beiner et al., 2006). Similarly the size of the board is also showing positive relationship with accounting based measure of the profitability such as ROA (Haniffa and Hudaib, 2006; Sanda et al., 2005). This suggests that differences exist between investors and companies in their perception of the relevance of larger boards. Theoretically, the finding of Haniffa and Hudaib (2006) implies that larger boards enhance the knowledge base on which business advice can be sought, which increases resource dependence capability to make important and better business decisions.

Brennan (2006) is of the view that an adequate level of efficiency and effectiveness is needed on behalf of board of directors to safe guard the interest of the shareholders. Therefore, in the light of above discussion the following hypotheses are put forth:

H2 (a): Board Size is positively associated with firm financial performance (Tobin Q)

$\mathrm{H} 2$ (b): Board size is positively associated with firm financial performance (ROA)

According to Agency and Resource dependence theorists, boards dominated by executive directors are relatively less answerable to diverse shareholders (Fama, 1980; Sonnenfeld, 2002). Therefore, presence of non-executive directors is deemed beneficial for the outside 
investors. The NEDs are considered useful in bringing independence to board decisions (Combined code, 2012; Chhaochharia and Grinstein, 2007) and adding the resources to the firm in the shape of experience, expertise, business contacts and reputation (Klein, 2003; Haniffa and Hudaib, 2006; Baranchuk and Dybvig, 2009).

Brick and Chidambaran (2007) find some evidence of a positive relationship between independent directors and board meetings which can have a plausible explanation that more members would need more time to be briefed about the situation and would consequently need more time to discuss the issues on the board and hence will be demanding more number of board meetings. The evidence also suggests that when board meet infrequently, they are hardly able to exert any meaningful influence over corporate performance (Useem, 2006).Guest (2009) finds a strong empirical foundation for the monitoring role of the board based upon the board size. Al-Najjar (2012) suggests that presence of more independent directors on the board will increase the frequency of board meetings. Consequently, more meetings will permit directors to give more time for strategy formation and performance appraisal. Therefore, if higher board activity facilitates better board monitoring, outside directors are likely to demand more board meetings to enhance their ability to monitor management. Simultaneously, in boards with more outsider participation, more time is likely to be spent in briefing board members than would be required in boards with high insider membership. Thus there should be a positive relation between the representation of outside directors on the board and the level of board activity.

Consequently, this study proposes to further this research by examining the extent to which governance codes affect board structure to strengthen board roles and firm performance. Accordingly, the following stream of hypothesis would be:

H3(a1): There is positive relationship between proportion of Non-Executive Directors and frequency of board meetings

H3(a2): There is positive relationship between proportion of Non-Executive Directors and board size

H3(b1):The relationship between proportion of NEDs and firm performance (Tobin Q) is mediated by board control role (frequency of board meetings) and board resource dependence role (board size).

H3(b2):The relationship between proportion of NEDs and firm performance (ROA) is mediated by board control role (frequency of board meetings) and board resource dependence role (board size).

CEO duality refers to a board leadership structure in which one person undertakes the combined roles of chief executive officer (CEO - management) and chairman of the board. The chairman of the board is responsible for managing the board. In contrast, the CEO is responsible for the day-to-day management of the company, including implementing board decisions.

Weir et al, (2002) explain that the resource dependence theory supports the dual role of the CEO and board chairperson as they found that firms with existence of role duality had better performance. According to this theory if the CEO has dual powers he will be able to focus more closely on the firm objectives by knowing the organization affairs in more depth (Haniffa and Hudaib, 2006).

However, there is no scarcity of the literature regarding negative effect of CEO duality on firm performance (Haniffa and Cooke, 2002). As indicated by Jensen (1993) the role duality increases the agency problem because powerful CEOs may not be accountable to the board as well as their role as CEO overshadows their role as chairperson and in this way the board's effectiveness to monitor is compromised and they start protecting and defending the 
executives. Therefore, separating the roles between two people will improve the board capability to monitor as well as curtail the entrenchment behaviour by a CEO (Lipton and Lorsch, 1992; Haniffa and Cooke, 2002). It will also help get rid of a non-performing CEO (Monks and Minow, 2001). This can help in developing mechanism to curtail agency problems by preventing managers from pursuing goals that advance their self-interests to the disadvantage of shareholders. Therefore, our hypotheses would be:

H4(a1): There is a negative relationship between role duality and frequency of board meetings

$\mathrm{H} 4(\mathrm{a} 2)$ : There is a negative relationship between role duality and board size

H4(b1 ): The relationship between CEO duality and firm performance (Tobin Q) is mediated by frequency of board meetings (control role) and board size (resource dependence role).

H4(b2 ): The relationship between CEO duality and firm performance (ROA) is mediated by frequency of board meetings (control role) and board size (resource dependence role).

\section{The Conceptual Model}

Figure 1

Board Structural Characteristics

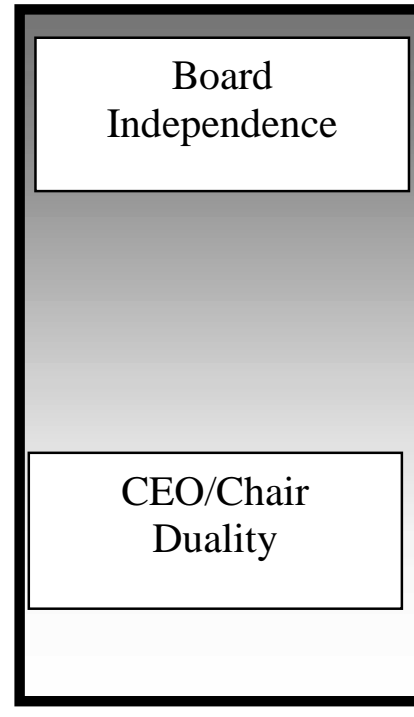

Board Roles

Firm Performance

\section{METHODOLOGY}

In this study, the quantitative approach seems the most appropriate to establish the relationship between board structural characteristics, board roles and firm performance following the board research studies for example Gabrielsson and Winlund, (2000); Van den Berghe, (2007) and Minichilli et al., (2009).

The data collection technique used in this study is based upon the analysis of previously collected data in the form of annual reports which comprise of official and certified statistics of public listed companies on the Karachi stock Exchange (KSE) of Pakistan from year 1999 to 2005. To qualify for the final sample, a firm has to complete the following two decisive 
factors: Firstly a company's full six-year annual reports from 1999-2005 both periods inclusive must be available. Secondly, its corresponding six year stock market and financial accounting related information must also be available for calculating Tobin Q. Table 1 presents a summary of the sample selection procedure. Appendix-A gives the names of all the companies included in the final sample. Together, the four industries account for approximately $69 \%$ of the entire KSE population of listed firms.

It is also in line with prior researchers of corporate governance who have used panel data (Yermack, 1996; Gompers et al., 2003; Bhagat and Bolton, 2008; Brick and Chidambaran, 2010). This study uses panel data for a period of six years from 1999 to 2005 .

The Hausman specification test is the classical test to determine whether the data possesses the fixed or random effects. This study found out, after applying Hausman test by using STATA, that null hypothesis on no correlation between firm-specific effects and regressors can't be rejected because the value for chi $2=4.67$, Prob $>\operatorname{chi} 2=0.8453$ and $\operatorname{chi} 2=4.45$, Prob $>$ chi $2=0.8148$ for both the models respectively which clearly indicates that Prob $>$ chi2 is higher than $5 \%$ and is insignificant for both the models which shows that the assumptions for the fixed effects estimators are not feasible and statistic favours random effect.

Test for Autocorrelation: Serial correlation causes the standard errors of the coefficients to be smaller than they actually are and report higher R-squared. The null is no serial correlation. Our test results reveal that $F(1,200)=0.214$ and Prob $>F=0.6603$. Therefore, the null can't be rejected and it can be conclude that the data does not have first-order autocorrelation.

According to Chatterjee and Price (1991) the value of the variance inflation factor (VIF) larger than 10 then it is the evidence of multicollinearity as well as a mean of the factors considerably larger than one suggests multicollinearity. In our case the mean value of VIF are $2.53<10$ as well as individually none of the variables had VIF more than 10 thus no muticollinearity in the data.

Yermack (1996) and Himmelberg et al. (1999) are of the view that the problem of endogeneity can be overcome through using panel estimation techniques. Such an assumption is plausible within a panel dataset exhibiting a small time series and large cross section, as unobservable firm attributes are improbable to vary significantly over a small period of time. Therefore this study is implementing a random effects panel specification in an attempt to overcome estimation issues associated with endogeneity.

To explore the nature of the mediation, the researcher also used the Sobel test (Preacher and Kelley, 2011; Sobel, 1982). Given that the model used in the study has a two-step mediation process, the researcher ran multiple Sobel tests on the actual mediation effects of all relationships. There is no significant mediating effect if the Sobel test $z$-value is not significant such as less than 1.96 , the mediation relationship is partial if the Sobel test z-value is significant such as more than 1.96 and the full mediation relationship exist if the Sobel test $\mathrm{z}$-value is significant (> 1.96) and the effect ratio is greater than 0.8 (Jose, 2008).

\section{Dependent variables: Firm Performance}

This study uses the financial performance as dependent variable. The study adopts the two distinctive measurements of the financial performance based upon the prior literature such as Gompers et al. (2003), Klapper and Love (2004), Haniffa and Hudaib (2006), and Guest (2009), these two measurements are return on assets (ROA) and Tobin's Q which represent the accounting and market based measures of financial performance, respectively.

The researcher has proxied the research and development ratio by dividing capital expenditure to total sales (Capex) by following the prior literature (Brown et al., 2009).

The leverage is used as a proxy for the ratio of total debt to total assets and it is also in line with the previous literature (Klapper and Love, 2004; Bhagat and Bolton, 2008). 
The firm size is calculated as a natural $\log$ of total assets of a firm and Directors shareholdings is calculated as ratio of the total number of ordinary shares held by all directors divided by the total number of outstanding ordinary shares in the market.

\section{Independent Variables:}

These include: the proportion of non-executive directors (\%_NED) and role or CEO duality (CEOdual). The proportion of non-executive directors is the total number of non-executive directors divided by the total number of directors on the board (Haniffa and Hudaib, 2006). CEO duality (CEOdual) is a dummy variable that takes the value of " 1 " if the positions of company chairman and CEO are combined, otherwise "0" (Brick and Chidambaran, 2010; Kiel and Nicholson, 2003).

\section{Mediating Variables:}

There are two mediating variables, board control role and resource dependence role. The board control role is measured as the frequency of board meetings (FOBM) whereas, the board resource dependence role is measured by Board size (board_ size) which is the total number of directors serving on a company's board at the end of the financial year.

\section{Data Analysis:}

The initial data analysis revealed that the data exhibited a reasonable variability.

Regression Results with Random Effects with Monitoring Role of the Board and the Performance Measure as Tobin Q

In Model M0 in Table 4, the controlled variables have been regressed against the performance measure of Tobin Q. In the next step, independent variables have been added to the model with the interaction term SECP in the next model, M1. The results in M1 show marginally significant positive relationship for proportion of non-executive directors on the board $(\beta=.68, \mathrm{p}<.1)$ and negative relationship for the dual role of $\mathrm{CEO} / \mathrm{Chairman}$ of the board respectively $(\beta=-.79, \mathrm{p}<.1)$ and independence of audit committee $(\beta=1.34, \mathrm{p}<.1)$. The fit statistics for $\mathrm{M} 1$ are $\mathrm{R}^{2}=.108, \chi^{2}=126.15$ (12df, $\left.\mathrm{p}<.001\right)$, which are relatively higher than M0.

To assess the effect of independent variables on mediating variable as the first condition of mediation, Tobin $\mathrm{Q}$ as performance measure was regressed on governance indicators. The first regression model provides the results of relationship between governance indicators and Tobin Q (columns M1). The results from M1 provide sufficient evidence for the first condition of mediation as recommended by Baron and Kenny (1986).

In M2, the second condition of mediation is assessed by regressing board monitoring role (Frequency of board meetings) on governance indicators. The value for the proportion of non-executive directors is also positive and significant $(\beta=.248, \mathrm{p}<.05)$ showing that more presence of NEDs on the board increases the board meeting frequency causing improved monitoring role of the board. The variable dual role of CEO/Chairman of the board is negative and significant $(\beta=-.267, \mathrm{p}<.05)$ which shows that as the dual role increases the frequency of board meetings decreases. The value of fit statistics is $\mathrm{R} 2=.306$ and $\chi^{2}=334.83$ $(12 \mathrm{df}, \mathrm{p}<.001)$ for this model which elaborates that almost $30 \%$ of the variance in the model is accounted for these variables.

To test for the final condition of mediation both governance indicators and board monitoring role were added in the model M3 and Tobin Q is regressed on board monitoring role 
(Frequency of board meetings) and governance indicators. The value of fit statistics is R2 = .112 and $\chi^{2}=135.83$ (13df, $\mathrm{p}<.001$ ) for this model which elaborates that almost $11 \%$ of the variance in the model is accounted for these variables.

Table 4: Regression Results by using Random Effects with Monitoring Role of the Board and the Performance Measure as Tobin Q

Independent Variables (IV): \%age of Non-Executive Directors, Dual Leadership, Dependent Variable (DV): Tobin Q; Mediating Variable (MV): Frequency of Board Meetings;

$\dagger \mathrm{p}<.1, * \mathrm{p}<.05, * * \mathrm{p}<.01, * * * \mathrm{p}<.001$

Regression Results with Random Effects with Resource Dependence Role of the Board and the Performance Measure as Tobin Q

The results obtained from regression analysis by testing the relationships between Governance variables, Board Resource Provision role and Performance measure of are presented in Table 5. The results in M1 show marginally significant positive relationship for proportion of non-executive directors on the board $(\beta=.68, \mathrm{p}<.1)$ and marginally significant negative relationship for the dual role of CEO/Chairman of the board respectively $(\beta=-.79$, $\mathrm{p}<.1)$. The fit statistics for $\mathrm{M} 1$ are $\mathrm{R}^{2}=.108, \chi^{2}=126.15$ (12df, $\left.\mathrm{p}<.001\right)$, which are relatively higher than M0.

In M2 of table 5, the second condition of mediation is assessed by regressing board resource dependence role (Board Size) on governance indicators. The dual role of CEO is negative and significant $(\beta=-.226, \mathrm{p}<.05)$ which shows that as the dual role increases the frequency of board meetings decreases.

To test for the final condition of mediation both governance indicators and board resource provision role were added in the models M3. The Tobin Q is regressed on board resource provision role (board size) and governance indicators. The results show that the proportion of non-executive directors and independence of audit committee are somewhat significant and positive $(\beta=.183, \mathrm{p}<.1)$ and $(\beta=.42, \mathrm{p}<.1)$ respectively as well as the value of mediating variable board size is also positive and significant $(\beta=.16, \mathrm{p}<.01)$. There is partial mediation existing by board size for the proportion of non-executive directors. This implies that board size has been mediating the relationship between proportion of non-executive directors and Tobin Q which shows that if the proportions of NEDs have been higher, the larger will be board size or improved board resource dependence role eventually leading towards better performance (Tobin Q).

Table 5: Regression Results with Random Effects with Resource Dependence Role of the Board and the Performance Measure as Tobin Q.

$\dagger \mathrm{p}<.1,{ }^{*} \mathrm{p}<.05,{ }^{*} * \mathrm{p}<.01, * * * \mathrm{p}<.001$

$\mathrm{N}=200$, Control Variables: Consumer Goods, chemicals, Industrials, Firm Size, Leverage, Capex, Directors' Ownership with textiles taken as base variable.

Independent Variables (IV): \%age of Non-Executive Directors, Dual Leadership Dependent Variables (DV):TobinQ; Mediating Variable (MV): Board Size

Regression Results: Governance Indicators, Boards' Monitoring Role and Return on Assets as Firm Performance 
The results obtained from regression analysis by testing the relationships between Governance variables, Board monitoring role and performance measure of return on assets (ROA) are presented in Table 6. In the Model M0, the controlled variables have been regressed against the performance measure of ROA. The results in M1 show negative and significant relationship for the dual role of CEO/Chairman of the board respectively $(\beta=-$ $.088, \mathrm{p}<.1)$.

In M2, the second condition of mediation is assessed by regressing the mediating variable which is board monitoring role (frequency of board meetings) on governance indicators. More specifically, in M2 the board monitoring role (Frequency of board meetings) is regressed on governance indicators. The value for the proportion of non-executive directors is also positive and significant $(\beta=.248, \mathrm{p}<.05)$ showing that more presence of NEDs on the board increases the board meeting frequency causing improved monitoring role of the board. The variable dual role of CEO/Chairman of the board is negative and significant ( $\beta=-.267$, $\mathrm{p}<.05)$ which shows that as the dual role increases the frequency of board meetings decreases. The value of fit statistics is $\mathrm{R} 2=.306$ and $\chi^{2}=334.83$ (12df, $\mathrm{p}<.001$ ) for this model which elaborates that almost $30 \%$ of the variance in the model is accounted for these variables.

To test for the final condition of mediation both governance indicators and board monitoring role were added in the models M3. More specifically in M3 the Tobin Q is regressed on board monitoring role (frequency of board meetings) and governance indicators. The results show that the most of the variables are insignificant except dual role of $\mathrm{CEO} /$ chairman of the board which is somewhat slightly negative and significant $(\beta=-.085, \mathrm{p}<.1)$, the value of fit statistics is $\mathrm{R} 2=.218$ and $\chi^{2}=126.17(13 \mathrm{df}, \mathrm{p}<.001)$ for this model which elaborates that almost $21 \%$ of the variance in the model is accounted for these variables and the value of mediating variable is insignificant which violates the condition of mediation. Thus no mediation is found in case of M3.

N=200, Control Variables: Consumer Goods, chemicals, Industrials, Firm Size, Leverage, Capex, Directors 'Ownership with textiles taken as base variable.

Independent Variables (IV): \%age of Non-Executive Directors, Dual Leadership, Audit Committee Meetings, Independence of Audit Committee Dependent Variables (DV): Tobin Q; Mediating Variable (MV): Board Size;

$\dagger \mathrm{p}<.1,{ }^{*} \mathrm{p}<.05,{ }^{* *} \mathrm{p}<.01,{ }^{* * *} \mathrm{p}<.001$

Regression Results: Governance Indicators, Boards' Resource Provision Role and ROA as Firm Performance

The results obtained from regression analysis by testing the relationships between Governance variables, Board Resource Provision role and Performance measure of are presented in Table 7. In the Model M0, the controlled variables have been regressed against the performance measure of ROA. The regression relationship has been controlled by Consumer Goods, Chemicals, Industrials, Firm size, Leverage, R\&D ratio to Sales and Directors' shareholdings. This is a restricted model by using only control variables as predictors and the results reveal that there is no significant association found in this model with value of fit statistics is $\mathrm{R} 2=.185$ and $\chi^{2}=115.11(7 \mathrm{df}, \mathrm{p}<.001)$ for this model which elaborates that only almost $18 \%$ of the variance in the model is accounted for.

In the next step, independent variables have been added to the model, M1. The results reveal that there is a negative and significant relationship between dual role of CEO/Chairman board of directors and $\operatorname{ROA}(\beta=-.088, \mathrm{p}<.01)$ represents the overall value for company performance.

In M2, the second condition of mediation is assessed by regressing the mediating variable which is board resource dependence role (Board Size) on governance indicators. More 
specifically, in M2 the board resource dependence role (Board Size) is regressed on governance indicators. The value for the proportion of non-executive directors is insignificant. The variable dual role of CEO/Chairman of the board is negative and significant $(\beta=-.226, p<.05)$ which shows that as the dual role increases the board size decreases. The value of fit statistics is $\mathrm{R} 2=.126$ and $\chi^{2}=72.64$ (12df, $\left.\mathrm{p}<.001\right)$ for this model which elaborates that almost $12 \%$ of the variance in the model is accounted for these variables.

To test for the final condition of mediation both governance indicators and board monitoring role were added in the models M3. More specifically in M3 the ROA is regressed on board resource dependence role (Board Size) and governance indicators. The results show that the most of the variables are insignificant except dual role of $\mathrm{CEO} /$ chairman of the board which is negative and somewhat significant $(\beta=-.087, \mathrm{p}<.1)$, the value of fit statistics is $\mathrm{R} 2=.221$ and $\chi^{2}=121.69$ (13df, $\mathrm{p}<.001$ ) for this model which elaborates that almost $22 \%$ of the variance in the model is accounted for these variables and the value of mediating variable is insignificant which violates the condition of mediation.

Results of the Sobel test also revealed that there is no mediation found as all the results are insignificant by using ROA as performance measure. The value of fit statistics is $\mathrm{R} 2=.245$ and $\chi^{2}=134.16(17 \mathrm{df}, \mathrm{p}<.001)$.

Table 7: Regression Results with Random Effects with Resource Dependence Role of the Board and the Performance Measure as ROA

N=200, Control Variables: Consumer Goods, chemicals, Industrials, Firm Size, Leverage, Capex, and Directors' Ownership with textiles taken as base variable.

Independent Variables (IV): \%age of Non-Executive Directors, Dual Leadership, Audit Committee Meetings, Independence of Audit Committee

Dependent Variable (DV): Tobin Q;

Mediating Variable (MV): Frequency of Board Meetings; $\dagger \mathrm{p}<.1, * \mathrm{p}<.05, * * \mathrm{p}<.01, * * * \mathrm{p}<.001$

\section{CONCLUSION AND CONTRIBUTIONS OF THE STUDY}

There are three key contributions to theory arising from this study. Firstly, board roles better predict firm performance with respect to market measures as compared to accounting measures of firm performance.

Secondly, by probing several board structural characteristics and multiple board roles (Monitoring role and resource dependence role) simultaneously, this study provides a more inclusive and wide-ranging treatment of board research. Thirdly, the board structural variables more strongly relate with the monitoring role of the board and market measure of firm value. These findings have implications for board practice, board theory, and board policy makers. Parting its ways from conventional input-output mechanism based studies and finding its motivation more from indirectly measuring the board structural characteristics and firm performance relationship through board roles mediation, this study shows that board structural characteristics are better predictors of board monitoring activity (FOBM) and board resource dependence (Board size) roles as compared to firm performance. These findings support the other more recent studies on boards of directors (Brick and Chidambaran, 2010) and (Linck et al., 2009). 
This study advances knowledge about the factors that influence firm performance and the influences on the control role and resource dependence role of the board of directors in Pakistan. The results discussed previously in this section show that board structure and roles are more important in explaining firm performance. These findings are similar to a number of non-Pakistani studies (e.g. Van den Heuvel et al., 2006; Wan and Ong, 2005). Specifically, agency theorists advocate boards should have a majority of NEDs, and a separate CEO and Chairperson of the board to perform effectively the monitoring function (Fama, 1980; Fama and Jensen, 1983; Jensen and Meckling, 1976). The importance of board structure is also recognised in resource dependency theory. The resource dependence theorists advocate that the primary role of the board is a resource provider linking the organisation with its external environment (Hillman and Dalziel, 2003). The resource dependence role demands from them that board members should bring legitimacy to th firm by providing the strategic resources to the firm in the shape of expertise and advice (Carpenter and Westphal, 2001; Gales and Kesner, 1994; Hillman et al., 2000; Pfeffer and Salancik, 1978). Therefore, it is imperative that directors bring diverse resources to the organization because of their different backgrounds. (Hillman et al., 2000). Thus, according to resource dependency, larger boards are better able to bring such resources (Hillman et al., 2000; Hillman and Dalziel, 2003; Hill man et al., 2009).

\section{Limitations of the study and future research:}

The sample size was not consisting of all nonfinancial sector firms registered on KSE. The data was consisting of textile firms majorly but the sample taken was also a representative of overall population as the number of textile firms registered outnumbers any other sector on the stock exchange in Pakistan. The findings and limitations of this study point to a number of areas requiring further research. First, a study examining the impact of different board structural characteristics on board roles, and firm performance is an area worthy of further exploration. Second, the board roles may be measured by using an interactive process instead of using fixed proxies.

\section{REFERENCES:}

Aguliera, R.V. (2005) Corporate governance and director accountability: an institutional perspective, British Journal of Management, S39-S53

Al-Najjar, B. (2012) The determinants of the frequency of board meetings: Evidence from categorical analysis Journal of Applied Accounting Research, 13(2), pp.178 - 190.

Baranchuk, N. and Dybvig, P. (2009). 'Consensus in Diverse Corporate Boards', The Review of Financial Studies, Vol. 22, No. 2, Pp.715-747.

Beiner, S., Drobetz, W., Schmid, M. M. and Zimmermann, H. (2006), An Integrated Framework of Corporate Governance and Firm Valuation. European Financial Management, 12: 249-283. doi: 10.1111/j.1354-7798.2006.00318.x

Brennan, N. (2006), "Boards of directors and firm performance: is there an expectations gap?", Corporate Governance: An International Review, Vol. 14 No. 6, November, pp. 577-593.

Brick, Ivan E. and Chidambaran, N.K., Board Meetings, (2007) Committee Structure, and Firm Performance. Available at SSRN: http://ssrn.com/abstract=1108241 or http://dx.doi.org/10.2139/ssrn.1108241

Brick, I., Chidambaran, N. K. (2010). Board meetings, committee structure, and firm value, Journal of Corporate Finance, 16: 533-553. http://dx.doi.org/10.1016/j.jcorpfin.2010.06.003 
Brown, J. R., Fazzari, S. M. and Petersen, B. C. (2009). 'Financing Innovation and Growth:Cash Flow, External Equity, and the 1990S RandD Boom', The Journal of Finance, Vol. LXIV, No. 1, Pp.185.

Carpenter, M.A. and Westphal, J.D. (2001) The strategic context of external network ties: examining the impact of director appointments on board involvement in strategic decision making, Academy of Management Journal, 4 (4), 639-660

Chatterjee, S. and Price, B. (1991). Regression analysis by example. New York: John Wiley.

Chhaochharia, V. and Grinstein, Y. (2007). 'Corporate Governance and Firm Value: The Impact of the 2002 Governance Rules', Journal of Finance, Vol. 62, No. 4, Pp.17891825.

Conger, J. A., Finegold, D. and Lawler, E. E. III (1998). 'Appraising Boardroom

Performance', Harvard Business Review, Vol. 76, No. 1, Pp.136-148.

Dahya, J. and McConnell, J. J. (2005). 'Outside Directors and Corporate Board Decisions', Journal of Corporate Finance, Vol. 11, Pp.37-60.

Daily, C., Dalton, D. R. and Cannella, A. A. (2003). 'Corporate Governance: The Impact of Board Composition and Structure, Academy of Management Journal, Vol. 28, Pp.371-382.

Fama, E. F. (1980). 'Agency Problems and the Theory of the Firm', Journal of Political Economy, Vol. 88, No. 2, Pp288-307.

Fama E. F. and Jensen, M. C. (1983). 'Separation of Ownership and Control', Journal of Law and Economics, Vol. 26, No. 2, Pp.301-325.

Gabrielsson, J., and Winlund, H. (2000) Boards of directors in small and medium-sized industrial firms: examining the effects of the board's working style on board task performance, Entrepreneurship and Regional Development, 12, 311-330

Ghoshal, S. (2005) Bad management theories are destroying good management practice, Academy of Management learning and Education, 4 (1), 75-91

Gompers, P., Ishii, J., and Metrick, A. (2003) Corporate governance and equity prices, Quarterly Journal of Economics, 118 (1), 107-155

Guest, P. M. (2009). 'The Impact of Board Size on Firm Performance: Evidence from the

UK', The European Journal of Finance, Vol. 15, No. 4, Pp.385-404.

Guest, P. M. (2008) The determinants of board size and composition: Evidence from the UK, Journal of Corporate Finance, 14, 51-72.

Haniffa, R. and Hudaib, M. (2006). 'Corporate Governance Structure and Performance of Malaysian Listed Companies', Journal of Business, Finance and Accounting, Vol. 33, No. 7 and 8, Pp.1034-1062.

Haniffa, R. M. and Cooke, T. E. (2002). 'Culture, Corporate Governance and Disclosure in Malaysian Corporations', Abacus, Vol. 38, No. 3, Pp.317-349.

Henry, D. (2008). 'Corporate Governance Structure and the Valuation of Australian Firms: Is there Value in Ticking the Boxes', Journal of Business Finance and Accounting, Vol. 35, No. 7 and 8, Pp.912-942.

Hermalin, B.E. and Weisbach, M.S. (2003) Boards of directors as an endogenously determined institution: a survey of the economic literature, Economic Policy Review, 9 (1), 7-26

Hillman, A.J., Cannella, Jr., AR., and Paetzold, R.L. (2000) The resource dependence role of corporate directors: Strategic adaptation of board composition in response to environmental change, Journal of Management Studies, 37 (2), 235-255 
Himmelberg, C. P., Hubbard, R. G. and Palia, D. (1999). 'Understanding the Determinants of Managerial Ownership and the Link Between Ownership and Performance', Journal of Financial Economics, Vol. 53, Pp.353-384.

Huse, M. (2005) Accountability and creating accountability: a framework for exploring behavioural perspectives of corporate governance, British Journal of Management, 16, S65-S79

Jensen, M. C. (1986). 'Agency Costs of Free Cash Flow, Corporate Finance, and Takeovers', American Economic Review, Vol. 76, No. 2, Pp.323-329.

Jensen, M.C. (1993) The modern industrial revolution, exit, and the failure of internal control systems, Journal of Finance, 48, 831-880

Jensen, M. C. and Meckling, W. H. (1976). 'Theory of the Firm: Managerial Behaviour, Agency costs and Ownership Structure', Journal of Financial Economics, Vol. 3, Pp.305-360.

Klapper, L. F. and Love, I. (2004). 'Corporate Governance, Investor Protection, and Performance in Emerging Markets', Journal of Corporate Finance, Vol. 10, Pp.703728.

Klein, A., (2003). Likely effects of stock exchange governance proposals and SarbanesOxley on corporate boards and financial reporting. Accounting Horizons 17 (4), 343355.

Linck, J.M. Netter, T. Yang (2008) The determinants of board structure Journal of Financial Economics, 87 (2008), pp. 308-328

Lipton, M. and Lorsch, J. W. (1992) A modest proposal for improved corporate governance, Business Lawyer, 48, 59- 77.

Mangena, M. and Tauringana, V. (2006). 'Corporate Boards, Ownership Structure and Firm Performance in an Environment of Economic and Political Instability: The Case of Zimbabwe Stock Exchange Listed Companies', Working Paper, School of Management, Bradford University, UK.

Minichilli, A., Zattoni, A., Nielson, S., and Huse, M. (2010) Board task performance: An exploration of micro- and macro-level determinants of board effectiveness, Journal of Organisational Behaviour, DOI: 10.1002/job.743

Minichilli, A., Zattoni, A., and Zona, F. (2009) Making boards effective: An empirical examination of board task performance, British Journal of Management, 20 (1), 55-74

Monks, R. A. G. and Minnow, N. (2001), Corporate Governance, Second Edition, Blackwell,

Oxford.

Monk, R., and Raphael, F. (2000) The great philosophers, London: Weidenfeld and Nicolson.

Pearce II, J.A. and Zahra, S.A. (1992) Board composition from a strategic contingency perspective, Journal of Management Studies, 29.

Pfeffer, J (1972) Size and composition of corporate boards of directors: The organisation and its environment, Administration Science Quarterly, 17(2), 218-228

Pfeffer, J., and Salancik, G. (1978) The external control of organisations: A resource dependence perspective, New York: Harper and Row

Preacher, Kristopher J. and Kelly, Ken (2011) Effect Size Measures for Mediation Models: Quantitative Strategies for Communicating Indirect Effects Psychological Methods 2011, Vol. 16, No. 2, 93-115 1082-989X/11/\$12.00 DOI: 10.1037/a0022658

Pugliese, A., Bezemer, P-J., Zattoni, A., Huse, M., Van den Bosch, A.J., and Volbreda, H.W. (2009) Board of directors' contribution to strategy: A literature review and research agenda, Corporate Governance: An International Review, 17 (3), 292-306

Pye, A., and Pettigrew, A. (2005) Studying board context, process and dynamics: Some challenges for the future, British Journal of Management, 16, S27-S38 
Reingold, J. (2000). Dot.com boards are flouting the rules. They're small and packed with insiders. Does it matter? Business Week (January 17): 130-135.

Roberts, J., McNulty, T., and Stiles, P. (2005) Beyond agency conceptions of the work of the nonexecutive director: creating accountability in the boardroom, British Journal of Management, 16, S5-S26

Sanda, A., Mikailu, A. S. and Garba, T. (2005). 'Corporate Governance Mechanisms and Firm Financial Performance in Nigeria', AERC Research Paper 149, Nairobi, Kenya.

Shleifer, A. and Vishny, R.W., (1997) A survey of corporate governance, Journal of Finance, $52(2), 737-783$

Sobel, Michael E. (1982), "Asymptotic Confidence Intervals for Indirect Effects in Structural Equation Models" in Samuel Leinhardt (ed.) Sociological Methodology, San Francisco: Jossey-Bass, pp. 290-312

Sonnenfeld, J. A. (2002). What Makes Great Boards Great. Harvard Business Review, 80(9), 106-113.

Tobin, J. (1969). 'A General Equilibrium Approach to Monetary Theory', Journal of Money, Credit, and Banking, Vol. 1, No. 1, Pp.15-29.

Useem, Michael (2006), "Oversight and Delegation in Corporate Governance: Deciding What the Board Should Decide", Corporate Governance

Vafeas, N., (1999)., Board meeting frequency and firm performance, Journal of Financial Economics 53, 113-142.

Van den Berghe L., Levrau A. (2007). Evaluating boards of directors: what constitutes a good corporate board? Corporate Governance - An international Review. 12(4): 461-478.

Van den Heuvel, Jeroen and Van Gils, Anita and Voordeckers, Wim, (2006). Board roles in small and edium-sized family businesses: performance and importance. Corporate Governance, Vol. 14, Iss. 5, pp. 467-485.

Van Ees, H., Gabrielsson, J., and Huse, M. (2009). Toward a Behavioral Theory of Boards and Corporate Governance. Corporate Governance-an International Review, 17(3): 307-319.

Wan, D. and Ong, C.H. (2005) Board structure, process and performance: evidence from public-listed companies in Singapore, Corporate Governance: An International Review, 13 (2), 277-290

Westphal, J.D. (1999) Collaboration in the boardroom: Behavioral and performance consequences of CEO-Board ties, Academy of Management Journal, 42(1), 7-24

Yawson, A. (2006). 'Evaluating the Characteristics of Corporate Boards Associated with Layoff Decisions', Corporate Governance: An International Review, Vol. 14, No. 2, Pp.75-84.

Yermack, D. (1996) Higher market valuation of firms with a small board of directors,

Zahra, S.A., and Pearce II, J.A. (1989) Boards of directors and corporate financial performance: A review and integrative model, Journal of Management, 15(2), 291334 


\section{APPENDIX}

Table 1: Sample Characteristics

\begin{tabular}{|l|l|l|l|l|}
\hline Type of Business & $\begin{array}{l}\text { Number of } \\
\text { Companies } \\
\text { (Data } \\
\text { Available) }\end{array}$ & $\begin{array}{l}\text { Total Sample Size } \\
(\mathrm{n}=200)\end{array}$ & $\begin{array}{l}\text { Total no. of } \\
\text { companies } \\
\text { listed }\end{array}$ & $\begin{array}{l}\text { \%on-financial } \\
\text { Companies listed } \\
(\mathrm{n}=464)\end{array}$ \\
\hline Textiles & 80 & $40 \%$ & 220 & $47 \%$ \\
\hline Consumer goods & 50 & $25 \%$ & 104 & $22 \%$ \\
\hline Chemicals & 36 & $18 \%$ & 70 & $16 \%$ \\
\hline Industrials & 34 & $17 \%$ & 70 & $15 \%$ \\
\hline
\end{tabular}

The initial data analysis revealed that the data exhibited a reasonable variability.

Table 2: Summary Statistics

\begin{tabular}{|r|l|l|l|l|}
\hline & Mean & Stand. Dev & Minimum & Maximum \\
\hline Tobin Q & 1.48 & 1.09 & .163 & 5.52 \\
\hline Return on Assets (\%) & 6.52 & 11.43 & -17.42 & 1.0 \\
\hline Frequency of Board Meetings & 4.82 & 2.99 & 0 & 33 \\
\hline Non-Executive Directors (\%) & .44 & 23.0 & 0 & 80.0 \\
\hline CEO-Chairman-Duality & .550 & .486 & 0 & 1 \\
\hline Board Size & 9.00 & 1.22 & 6 & 14.0 \\
\hline Leverage (\%) & 24.61 & 16.84 & -1.70 & 15.21 \\
\hline Directors' Share (\%) & 24.66 & 19.81 & 0 & .81 \\
\hline Capital Expenditure (\%) & 4.20 & 4.01 & .24 & 10.69 \\
\hline Firm Size & 13.40 & 1.160 & 6.89 & 16.10 \\
\hline
\end{tabular}


Table 3: Pearson Correlation Matrix of Financial Performance and Corporate Governance Variables

\begin{tabular}{|c|c|c|c|c|c|c|c|c|c|c|}
\hline Variables & 1 & 2 & 3 & 4 & 5 & 6 & 7 & 8 & 9 & 10 \\
\hline 1. Tobin Q & 1 & & & & & & & & & \\
\hline 2. R0A & $170^{* *}$ & 1 & & & & & & & & \\
\hline 3. FOBM & $.217^{*}$ & $.138^{*}$ & 1 & & & & & & & \\
\hline 4. NEDs & $.208^{* *}$ & $.064^{*}$ & $.208^{* *}$ & 1 & & & & & & \\
\hline 5. CEOdual & $-.222^{*}$ & $-.153^{*}$ & $-.121^{* *}$ & -.041 & 1 & & & & & \\
\hline 6. Board Size & $.186^{* *}$ & $.029^{*}$ & $.12^{*}$ & $33^{*}$ & $-.082^{* *}$ & 1 & & & & \\
\hline 7. Leverage & $.241^{*}$ & $-.376^{*}$ & $.026^{*}$ & $.069^{*}$ & $.206^{* *}$ & -.034 & 1 & & & \\
\hline 8. Director-Share & $-.024^{*}$ & $-.068^{*}$ & $-.258^{* *}$ & $-.196^{* *}$ & $.164^{* *}$ & $.167^{*}$ & $.069^{*}$ & 1 & & \\
\hline 9. Capex Ratio & .016 & -.049 & .023 & .003 & -.031 & $-.111^{*}$ & .046 & -.012 & 1 & \\
\hline 10. Firm Size & $.260^{*}$ & $204^{*}$ & $.043 \dagger$ & $.126^{*}$ & $-.149^{* *}$ & $.185^{* *}$ & $.442^{* *}$ & -.026 & $.094^{*}$ & 1 \\
\hline
\end{tabular}

**. Correlation is significant at the 0.01 level (2-tailed).

*. Correlation is significant at the 0.05 level (2-tailed). $\quad †$ Correlation is significant at the 0.1 level (2-tai

Table 4: Regression Results by using Random Effects with Monitoring Role of the Board and the Performance Measure as Tobin Q

\begin{tabular}{|c|c|c|c|c|c|c|c|c|c|c|c|}
\hline \multirow[t]{2}{*}{ Variables } & \multicolumn{2}{|c|}{ M0Controls } & \multicolumn{2}{|c|}{$\begin{array}{l}\text { M1 } \\
(X \rightarrow Y) \text { Cont }+\mathrm{IV}\end{array}$} & \multicolumn{2}{|c|}{ M3 $(\mathrm{X} \rightarrow \mathrm{M})$} & \multicolumn{3}{|c|}{$\mathrm{M} 5(\mathrm{X}, \mathrm{M} \rightarrow \mathrm{Y})$} & \multicolumn{2}{|c|}{ M7 $(\mathrm{M} \rightarrow \mathrm{Y})$} \\
\hline & B & S.E. & B & S.E. & B & S.E. & B & S.E. & \multirow{8}{*}{ 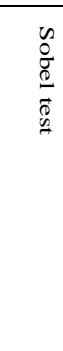 } & B & S.E. \\
\hline Cons. Goods & .094 & $(.211)$ & .129 & $(.214)$ & .057 & $(.043)$ & .067 & $(.208)$ & & .084 & $(.211)$ \\
\hline Chemicals & $-.397 \dagger$ & $(.240)$ & -.199 & $(.246)$ & .062 & $(.055)$ & -.254 & $(.241)$ & & $.397 \dagger$ & $(.240)$ \\
\hline Industrials & .188 & $(.258)$ & .352 & $(.260)$ & $.030^{*}$ & $(.016)$ & .313 & $(.256)$ & & .179 & $(.258)$ \\
\hline Firm Size & .121 & $(.081)$ & $.193^{*}$ & $(.082)$ & $.008 \dagger$ & $(.005)$ & .182 & $(.082)$ & & $.138 \dagger$ & $(.081)$ \\
\hline Leverage & -.024 & $(.441)$ & .050 & (.449) & $.013^{*}$ & $(.005)$ & .067 & (.449) & & -.075 & (.445) \\
\hline Capex & .267 & $(.519)$ & .168 & $(.515)$ & .039 & $(.031)$ & .212 & $(.510)$ & & .266 & (.519) \\
\hline Dir_Holdings & -.648 & (.414) & .598 & $(.505)$ & $-.060^{*}$ & $(.030)$ & .534 & $(.505)$ & & -.228 & $(.472)$ \\
\hline$\%$ NED & & & $.68 \dagger$ & (.403) & $.248^{*}$ & $(.124)$ & .146 & $(.511)$ & 0.94 & & \\
\hline CEOdual & & & $-.79 \dagger$ & $(.472)$ & $-.267^{*}$ & $(.123)$ & -.256 & $(.168)$ & -1.04 & & \\
\hline FOBM & & & & & & & .646 & $(.526)$ & & $.047^{*}$ & $(.024)$ \\
\hline $\mathrm{R}^{2}$ & \multicolumn{2}{|l|}{.093} & \multicolumn{2}{|l|}{.108} & \multicolumn{2}{|l|}{.306} & \multicolumn{3}{|l|}{.112} & \multicolumn{2}{|l|}{.101} \\
\hline$\chi^{2}$ & \multicolumn{2}{|c|}{106.89 (7 df, p<.001) } & \multicolumn{2}{|c|}{$\begin{array}{lll}126.15 & (12 \quad \mathrm{df}, \\
\mathrm{p}<.001) & & \end{array}$} & \multicolumn{2}{|c|}{$\begin{array}{lll}334.83 & (12 \quad \text { df, } \\
\mathrm{p}<.001) & & \end{array}$} & \multicolumn{3}{|c|}{$135.83(13 \mathrm{df}, \mathrm{p}<.001)$} & \multicolumn{2}{|c|}{$\begin{array}{l}117.05 \quad(8 \quad \mathrm{df}, \\
\mathrm{p}<.001)\end{array}$} \\
\hline
\end{tabular}

$\mathrm{N}=200$, Control Variables: Consumer Goods, chemicals, Industrials, Firm Size, Leverage, Capex, Directors' Ownership with textiles taken as base variable.

Independent Variables (IV): \%age of Non Executive Directors, Dual Leadership, Dependent Variable (DV): Tobin Q; Mediating Variable (MV): Frequency of Board Meetings; $\dagger \mathrm{p}<.1,{ }^{*} \mathrm{p}<.05, * * \mathrm{p}<.01, * * * \mathrm{p}<.001$ 


\begin{tabular}{|c|c|c|c|c|c|c|c|c|c|c|c|}
\hline \multirow[t]{3}{*}{ Variables } & \multirow{2}{*}{\multicolumn{2}{|c|}{$\begin{array}{l}\text { M0 } \\
\text { Controls }\end{array}$}} & \multirow{2}{*}{\multicolumn{2}{|c|}{$\begin{array}{l}\text { M1 }(X \rightarrow Y) \\
\text { Cont+IV }\end{array}$}} & \multirow{2}{*}{\multicolumn{2}{|c|}{$\mathrm{M} 2(\mathrm{X} \rightarrow \mathrm{M})$}} & \multirow{2}{*}{\multicolumn{3}{|c|}{$\mathrm{M} 3(\mathrm{X}, \mathrm{M} \rightarrow \mathrm{Y})$}} & \multirow{2}{*}{\multicolumn{2}{|c|}{$\mathrm{M} 4(\mathrm{M} \rightarrow \mathrm{Y})$}} \\
\hline & & & & & & & & & & & \\
\hline & B & S.E. & B & S.E. & B & S.E. & B & S.E. & $\begin{array}{l}\text { Sobel } \\
\text { Test }\end{array}$ & B & S.E. \\
\hline Cons. Goods & .094 & $(.211)$ & .129 & $(.214)$ & .315 & $(.290)$ & .105 & $(.209)$ & & .182 & $(.211)$ \\
\hline Chemicals & $-.397 \dagger$ & $(.240)$ & -.199 & (.246) & .174 & $(.204)$ & -.191 & $(.240)$ & & -.345 & $(.240)$ \\
\hline Industrials & .188 & $(.258)$ & .352 & $(.260)$ & .381 & $(.211)$ & $.469 \dagger$ & $(.259)$ & & .348 & $(.261)$ \\
\hline Firm Size & .121 & $(.081)$ & $.193^{*}$ & (.082) & $.242 \dagger$ & (.135) & $.158^{*}$ & $(.082)$ & & $.176^{*}$ & $(.082$ \\
\hline Leverage & -.024 & (.441) & .050 & (.449) & $.212^{*}$ & $(.111)$ & $.29 * *$ & $(.084)$ & & $.37^{* * * *}$ & (.094) \\
\hline Capex & .267 & $(.519)$ & .168 & $(.515)$ & -.314 & $(.242)$ & .075 & $(.511)$ & & .108 & $(.519)$ \\
\hline Dir_Holdings & -.648 & (.414) & .598 & $(.505)$ & -.001 & $(.217)$ & .534 & $(.499)$ & & $-690 \dagger$ & (.412) \\
\hline \%_NED & & & $.683 \dagger$ & (.403) & .204 & $(.171)$ & $.183 \dagger$ & $(.122)$ & $1.59 \dagger$ & & \\
\hline CEOdual & & & $-.79 \dagger$ & $(.472)$ & $-.226^{*}$ & $(.115)$ & -.194 & $(.169)$ & $-1.75 \dagger$ & & \\
\hline Board Size & & & & & & & $.16^{* *}$ & $(.052)$ & & $.238^{* *}$ & $(.080)$ \\
\hline $\mathrm{R}^{2}$ & \multicolumn{2}{|l|}{.093} & \multicolumn{2}{|l|}{.108} & \multicolumn{2}{|l|}{.126} & \multicolumn{2}{|l|}{.119} & & \multicolumn{2}{|l|}{.097} \\
\hline$x^{2}$ & \multicolumn{2}{|c|}{$\begin{array}{l}106.89 \\
p<.001)\end{array} \quad\left(\begin{array}{ll}7 & \text { df, }\end{array}\right.$} & \multicolumn{2}{|c|}{$\begin{array}{l}126.15 \quad(12 \quad d f, \\
p<.001)\end{array}$} & \multicolumn{2}{|c|}{$72.64(12 \mathrm{df}, \mathrm{p}<.001)$} & \multicolumn{3}{|c|}{127.64 (13 df, $p<.001)$} & \multicolumn{2}{|c|}{109.64 (9 df, p<.001) } \\
\hline
\end{tabular}

Table 6: Table 5.7: Regression Results with Random Effects with Monitoring Role of the Board and the Performance Measure as ROA

\begin{tabular}{|c|c|c|c|c|c|c|c|c|c|c|c|}
\hline \multirow[t]{3}{*}{ Variables } & \multicolumn{2}{|l|}{ M0 } & \multicolumn{2}{|c|}{ M1 $(X \dashv Y)$} & \multirow{2}{*}{\multicolumn{2}{|c|}{$\mathrm{M} 3(\mathrm{X} \rightarrow \mathrm{M})$}} & \multirow{2}{*}{\multicolumn{3}{|c|}{$\mathrm{M} 5(\mathrm{X}, \mathrm{M} \rightarrow \mathrm{Y})$}} & \multirow{2}{*}{\multicolumn{2}{|c|}{ M7 $(\mathrm{M} \rightarrow \mathrm{Y})$}} \\
\hline & \multicolumn{2}{|c|}{ Controls } & \multicolumn{2}{|c|}{ Cont+IV } & & & & & & & \\
\hline & B & S.E. & B & S.E. & B & S.E. & B & S.E. & \multirow{8}{*}{$\begin{array}{l}n \\
0 \\
0 \\
0 \\
0 \\
0 \\
0 \\
0\end{array}$} & B & S.E. \\
\hline Cons. Goods & .061 & .042 & .061 & $(.042)$ & .315 & $(.290)$ & $.054 \dagger$ & $(.033)$ & & $.071 \dagger$ & $(.042)$ \\
\hline Chemicals & $-.081 \dagger$ & $(.048)$ & .069 & $(.049)$ & .174 & $(.204)$ & -.059 & $(.044)$ & & .074 & $(.048)$ \\
\hline Industrials & -.025 & $(.051)$ & -.023 & $(.052)$ & .381 & $(.211)$ & .006 & $(.052)$ & & -.006 & $(.052)$ \\
\hline Firm Size & -1.03 & (.425) & -.019 & $(.430)$ & $.242 \dagger$ & $(.135)$ & .014 & $(.057)$ & & .016 & $(.061)$ \\
\hline Leverage & -.024 & $(.441)$ & .067 & $(.444)$ & $.212 *$ & $(.111)$ & .057 & \begin{tabular}{|l|}
$(.087)$ \\
\end{tabular} & & .032 & $(.087)$ \\
\hline Capex & .012 & $(.103)$ & .021 & (.103) & -.314 & $(.242)$ & .001 & $(.103)$ & & .007 & (.103) \\
\hline Dir_Holdings & -.060 & $(.082)$ & -.064 & $(.101)$ & -.001 & $(.217)$ & -.059 & $(.101)$ & & .065 & $(.082)$ \\
\hline$\%$ NED & & & .065 & $(.080)$ & .204 & $(.171)$ & .057 & $(.079)$ & 1.21 & & \\
\hline CEOdual & & & $-.088 * *$ & $(.034)$ & $-.226^{*}$ & $(.115)$ & $-.087 \dagger$ & $(.054)$ & -1.40 & & \\
\hline Board Size & & & & & & & .027 & $(.044)$ & & $.029 *$ & $(.015)$ \\
\hline $\mathrm{R}^{2}$ & \multicolumn{2}{|l|}{.185} & \multicolumn{2}{|l|}{.217} & \multicolumn{2}{|l|}{.126} & \multicolumn{3}{|l|}{.221} & \multicolumn{2}{|l|}{.198} \\
\hline$x^{2}$ & \multicolumn{2}{|c|}{$\begin{array}{l}115.11 \quad(\quad 7 \quad \mathrm{df}, \\
p<.001)\end{array}$} & \multicolumn{2}{|c|}{$\begin{array}{l}119.69 \\
p<.001)\end{array}$ ( $12 \mathrm{df}}$, & \multicolumn{2}{|c|}{$72.64(12 \mathrm{df}, \mathrm{p}<.001)$} & \multicolumn{3}{|c|}{$121.69(13 \mathrm{df}, \mathrm{p}<.001)$} & \multicolumn{2}{|c|}{117.22 (8df, p<.001) } \\
\hline
\end{tabular}

N=200, Control Variables: Consumer Goods, chemicals, Industrials, Firm Size, Leverage, Capex,

Directors'

Ownership with textiles taken as base variable.

Independent Variables (IV): \%age of Non Executive Directors, Dual Leadership, Audit Committee

Meetings, Independence of Audit Committee Dependent Variables (DV): Tobin Q; Mediating Variable

(MV): Board Size;

†p $<.1,{ }^{*} \mathrm{p}<.05,{ }^{*} \mathrm{p} p<.01,{ }^{*} * * \mathrm{p}<.001$ 
Table 8: Summary of Findings from Hypotheses Testing

\begin{tabular}{|l|l|l|}
\hline H1 (a) & Frequency of board meetings is positively associated with Tobin Q & Result \\
\hline H1 (b) & Frequency of board meetings is positively associated with ROA & Supported \\
\hline H2 (a) & Board size is positively associated with Tobin Q & Not supported \\
\hline H2 (b) & Board size is positively associated with ROA & Support \\
\hline H3 (a1) & Proportion of NEDs is positively associated with frequency of board meetings & Support \\
\hline H3 (a2) & Proportion of NEDs is positively associated with board size & Support \\
\hline H3 (b1) & The relationship between proportion of NEDs and Tobin Q is mediated by frequency of & Partially Supported \\
\hline & $\begin{array}{l}\text { The relationship between proportion of NEDs and ROA is mediated by board control role } \\
\text { and resource dependence role }\end{array}$ & \\
\hline & Role duality is negatively associated with frequency of board meetings & Supported \\
\hline H4 (a2) & There is a negative relationship between Role duality and board size & Supported \\
\hline H4 (b1) & The relationship between role duality and Tobin Q is mediated by board control role and & Supported \\
\hline & The relationship between role duality and ROA is mediated by board control role & and \\
\hline
\end{tabular}

